\title{
Immunocytochemical study of the distribuition of endocrine cells in the pancreas of the Brazilian sparrow species Zonotrichia Capensis Subtorquata (Swaison, 1837)
}

\author{
Nascimento, AA.*, Sales, A., Cardoso, TRD., Pinheiro, NL. and Mendes, RMM. \\ Departamento de Biologia Animal, Área de Histologia e Embriologia, Instituto de Veterinária, Sala 85, \\ Universidade Federal Rural do Rio de Janeiro - UFRRJ, \\ Rod. BR 465, Km 07, CEP 23890-000, Seropédica, Brasil \\ *e-mail: cidanasci@zipmail.com.br
}

Received November 24, 2005 - Accepted January 20, 2006 - Distributed November 30, 2007

(With 8 figures)

\begin{abstract}
In the present study, we investigated types of pancreatic endocrine cells and its respective peptides in the Brazilian sparrow species using immunocytochemistry. The use of polyclonal specific antisera for somatostatin, glucagon, avian pancreatic polypeptide (APP), YY polypeptide (PYY) and insulin, revealed a diversified distribution in the pancreas. All these types of immunoreactive cells were observed in the pancreas with different amounts. Insulin- Immunoreactive cells to (B cells) were most numerous, preferably occupying the central place in the pancreatic islets. Somatostatin, PPA, PYY and glucagon immunoreactive cells occurred in a lower frequency in the periphery of pancreatic islets.

Keywords: immunoreactive cells, endocrine cells, pancreas, bird.

\section{Estudo imunocitoquímico do pâncreas de Zonotrichia capensis subtorquata (Swaison, 1837)}

Resumo

Os tipos de células endócrinas e seus respectivos peptídeos reguladores foram estudados imunocitoquimicamente no pâncreas do tico-tico, espécie Zonotrichia capensis subtorquata, empregando-se o método imunocitoquímico $\mathrm{ABC}$ - Peroxidase (Complexo Avidina - Biotina - Peroxidase) e anti-soros específicos para somatostatina, ao glucagon, ao polipeptídeo pancreático aviário (PPA), ao polipeptídeo YY (PYY) e à insulina. Todos estes tipos de células imunorreativas foram observadas no pâncreas em quantidades diferentes. As células imunorreativas à insulina (células $\mathrm{B}$ ) foram as mais numerosas, ocupando preferencialmente, a região central das ilhotas pancreáticas. As células endócrinas imunorreativas à somatostatina, PPA, PYY e glucagon localizaram-se predominantemente na periferia das ilhotas.
\end{abstract}

Palavras-chave: células imunorreativas, células endócrinas, pâncreas, ave.

\section{Introduction}

There are many hormonal secretory cells releasing polypeptides and amines like 5 -hydroxytryptamine in the vertebrate digestive system. The secretion of these cells can be into blood (endocrine secretion) or by having an effect on neighboring cells (paracrine secretion). These cells are part of the APUD system, although at present this term has been replaced by diffuse neuroendocrine system. The presence of these cells in the pancreatic-gastrointestinaltract (PGIT) from different species of vertebrates has been corroborated by several surveys (Pan et al., 2000; Ku et al., 2000; Eerdunchaolu et al., 2001; Ku et al., 2003).

In many reported bird species, the presence, in the gizzard and proventriculus, of endocrine cells producing somatostatin, glucagon and APP (Yamada et al., 1986b; Cardoso et al., 1999) and in the pancreas has immunocytochemically shown endocrine cells producing glucagon, somatostatin, PPA and PYY (Cardoso et al., 1996; Lucini et al., 2000).

According to this context, our survey aimed to determine the somatostatin, glucagon, APP, PYY and insulin- immunoreactive cells in the pancreas of Brazilian sparrow species (Zonotrichia capensis subtorquata) by applying highly-specific antibodies and thus to contribute to the knowledge of secretory cells from gastrointestinal polypeptides in birds. 


\section{Material and Methods}

\subsection{Collection of samples and tissue processing}

Three adult Brazilian sparrows (Zonotrichia capensis subtorquata) were studied. The birds were caught at the Environmental Brazilian Institute (IBAMA) located in the Seropédica county in Brazil. The birds were sacrificed by ether inhalation and the pancreas was removed from each one and cut in smaller fragments for fixing in Bouin liquid (Di Fiori, 1975) for 24 hours. After postfixation the tissues were dehydrated in a graded series of ethanol and embedded in Paraplast. Sections of $5-\mu \mathrm{m}$ thickness were prepared on glass slides precoated with $0.1 \%$ poly-L-lysine (Sigma Chemical Co., Saint Quentin Fallavier, France), deparaffinized in methylcyclohexane, and returned to water through graded ethanol solutions. After washing, the sections were treated by avidin-biotin-peroxidase complex (ABC) (Hsu et al., 1981). The sections were pretreated for 5 minutes with $3 \%$ hydrogen peroxide solution before processing to immunocytochemistry.

Photomicrographies on microscope WILD M-20 with Kodacolor-100 microfilms were performed to specifically identify the endocrine-immunoreactive cells.

\subsection{Primary antisera}

The primary antisera were used for both the specificity controls and study of the interrelationship of cells immunoreactive to peptides or nonpeptide substances. They included guinea pig insulin antiserum (diluted 1:1.000; Immunonuclear Stilwater, USA), synthetic swine glucagon antiserum (diluted 1:10.000; Dr. Yanaihara Shizuoka, Japan), rabbit somatostatin antiserum (diluted 1:10.000; Dr. S. Ito Niigata, Japan), rabbit peptide APP antiserum (diluted 1:80.000; Dr. J.R. Kimmel, Kansas City, USA), rabbit peptide PYY antiserum (diluted 1:2.500; Immunonuclear Stilwater, USA).

\subsection{Single antigen immunocytochemistry}

For the immunocytochemical procedure the sections were processed at room temperature in a humid chamber by avidin-biotin-peroxidase complex (ABC) (Hsu et al. 1981). Microscope slides with fixed sections were treated for 2 hours at room temperature with a non immune serum (goat; Sigma), diluted 1:100 in PBS, and then incubated overnight at $4{ }^{\circ} \mathrm{C}$ with five of two primary region-specific antisera. The standard antibody dilutions used during immunocytochemistry were 1:1,000 for insulin; 1:10,000 for glucagon; 1:10,000 for somatostatin; 1:80,000 for APP; and 1,2500 for PYY. The antibody dilutions were made with $1 \%$ PBS in TBS. The peroxidase was reacted with a mixture of 3,3'-diaminobenzidine tetrahydrochloride $\left(0.1 \%\right.$ in PBS; Sigma) and $0.02 \% \mathrm{H}_{2} \mathrm{O}_{2}$. The slides were rinsed several times with deionized water, dehydrated through a series of alcohols and methylcyclohexanes, and coverslipped with Entelan (Merck)

\subsection{Double antigen immunocytochemistry}

To examine the coexpression of seven different peptides in the same cell, various immunocytochemi- cal approaches were applied. They included the adjacent section method, in which consecutive sections were incubated with different primary antisera. No crossreaction among antisera could occur, and consequently, there were no problems of specificity due to interference. However, a disadvantage of this method was the comparison of serial sections of $5-\mu \mathrm{m}$ thickness might result in equivocal pictures. Therefore, the second approach was indirect double staining, using two primary antisera raised in different species, mixed, and applied simultaneously to the tissue preparation at their predetermined optimal dilutions.

\subsection{Primary antiserum specificity controls}

In the present study, the immunocytochemical localization of peptides inside the endocrine cells was investigated by use of the polyclonal antiserum. Consequently, the region specificity of this antibody was tested in the immunocytochemical system and the specificity of this antiserum was examined by controls.

\subsection{Immunocytochemical tests}

The specificity of the immunostaining was demonstrated not only by the usual specificity tests (method controls), but also by extensive cross-reaction studies (antibody controls), as recommended previously (Heyderman, 1979). Method controls to validate the specificity of the binding of immunocytochemical reagents with tissue included: 1) omission of the primary antiserum, 2) replacement of the primary antiserum with nonimmune serum, 3) dilution profile of the primary antiserum using doubling dilutions on serial sections, 4) influence of the salt content (up to $0.5 \mathrm{M}$ ) of buffer, and 5) complement-deprived antisera. In addition, controls for the specificity of the double labeling were performed as follows: 1) using nonimmune serum as the first layer, and 2) using the labeled antisera without the presence of one or both primary antisera. Antibody controls to determine the specificity of interaction between the primary antiserum and the tissue-bound antigen were also used.

\section{Results}

\subsection{Localization of peptides in the pancreas}

The pancreas is the largest gland connected with the alimentary tract. It consists of an exocrine portion and the endocrine portion. In such portion the functions are both carried out by the some cells, the pancreas exocrine and endocrine functions that are performed by different groups of cells (Junqueira, 2004). The exocrine portion is a compound acinous gland whose lobules are bound together by loose vessels, neuronal fibers, lymphatic and excretory ducts. The acini drain their products into exocrine ducts which cluster in rounded and short tubules. Scattered cells throughout the endocrine portion of the pancreas constitute richly vascularized small masses of endocrine cells which represent the islets of Langerhans. They are more numerous in the tail of the pancreas than in its body or head. 
In our study the first category of cells comprised the ones associated predominantly with a subpopulation of cells in the endocrine pancreas. Insulin (B cells), PYY, APP, glugacon (A cells) and somatostatin (D cells) -immunoreactive endocrine cells were observed throughout the pancreatic gland, and their distribution was variable. Glucagon-immunoreactive cells and somatostatinimmunoreactive cells (Figures 1 and 2) were situated around the periphery and in the interior of the islet and APP-immunoreactive cells (Figure 3 ) were only detected

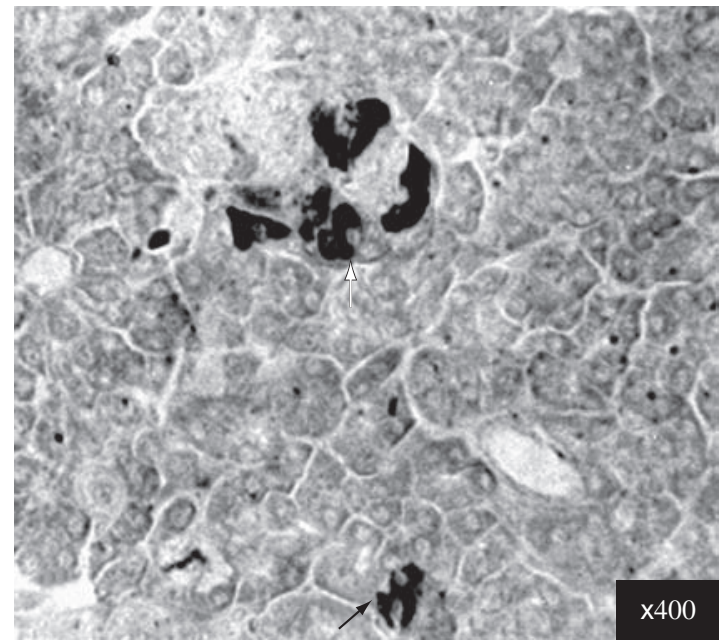

Figure 1. Optic photomicrography from the pancreas histological section of Zonotrichia capensis subtorquata. Note glucagon-immunoreactive cells placed in the islet of Langerhans (white arrow). Observe two stained cells at the exocrine portion (dark arrow). 400x.

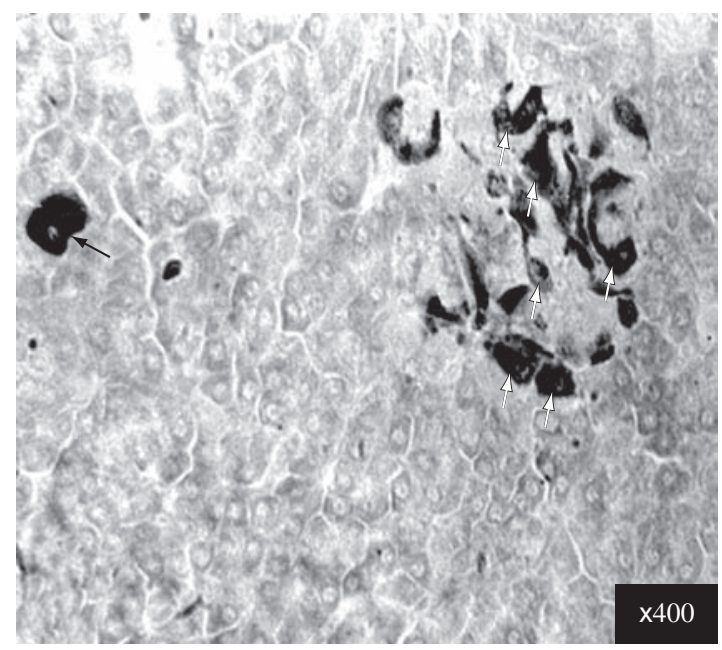

Figure 2. Optic photomicrography from the pancreas histological section of Zonotrichia capensis subtorquata. Note diffuse somatostatin-immunoreactive cells placed on the peripheral islet of Langerhans (white arrows). Observe two stained cells in the exocrine portion (dark arrow). 400x. in the periphery of the pancreatic islets. The insulin-immunoreactive cells tended to accumulate in the central portion of the islet (Figure 4).

The second category comprisedAPP-immunoreactive cells distributed in a greater amount between acinar (out islet) cells, isolated or together (Figure 5) in the pancreatic parenchyma. Insulin-containing cells were fewer numerous and, often isolated from the others (Figure 6). However, somatostatin-immunoreactive cells (Figure 7), glucagon-immunoreactive cells (Figure 1) and PYY-

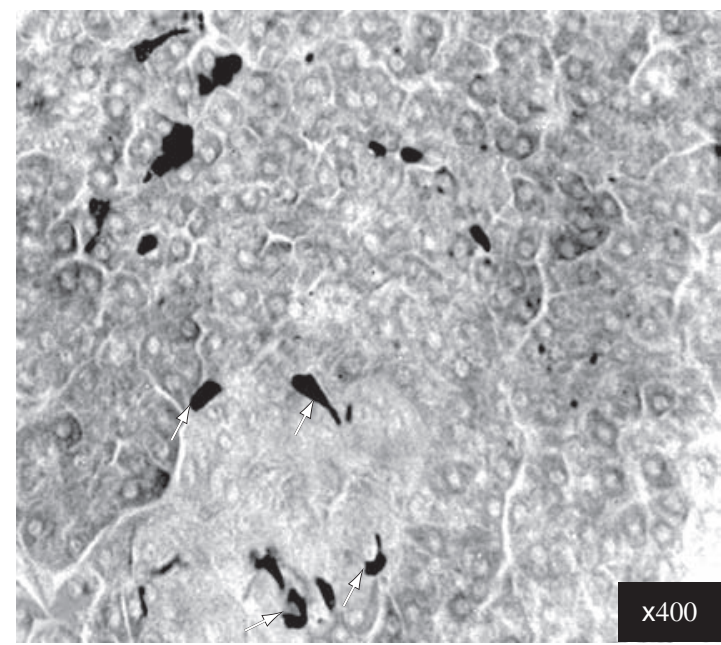

Figure 3. Optic photomicrography from the pancreas histological section of Zonotrichia capensis subtorquata. Note avian pancreatic polypeptide-immunoreactive cells placed on the periphery of an islet of Langerhans (arrows). 400x.

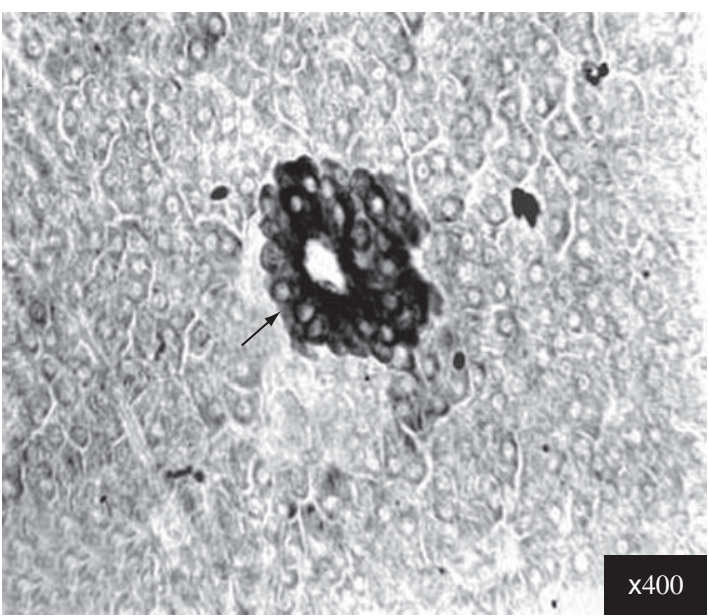

Figure 4. Optic photomicrography from the pancreas histological section of Zonotrichia capensis subtorquata. Note insulin-immunoreactive cells predominantly placed at the central region of an islet of Langerhans (arrow). 400x. 
immunoreactive cells (Figure 8) were detected in a smaller amount in the extra islets tissues.

In the present study, some glucagon immunoreactive cells, APP-immunoreactive cells and insulin-immunoreactive cells showed citoplasmatic extensions with terminals such as synaptic button (Figure 5).

\section{Discussion}

Topographic distribution of cells type D in Tangara seledon species (Cardoso et al., 1996) have been in agree-

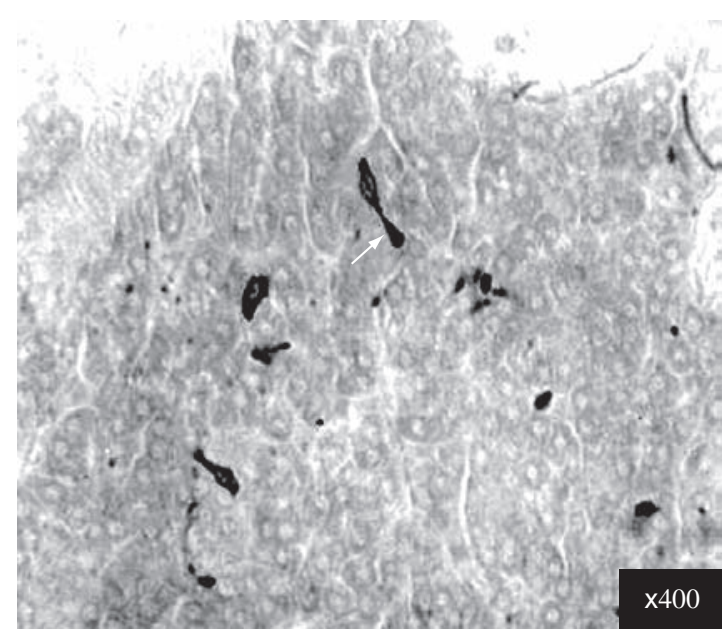

Figure 5. Optic photomicrography from the pancreas histological section of Zonotrichia capensis subtorquata. Note diffuse avian pancreatic polypeptide-immunoreactive cells placed in the exocrine portion. Observe a stained cell displaying a cytoplasmic outgrowth with its expanded ending (arrow). 400x.

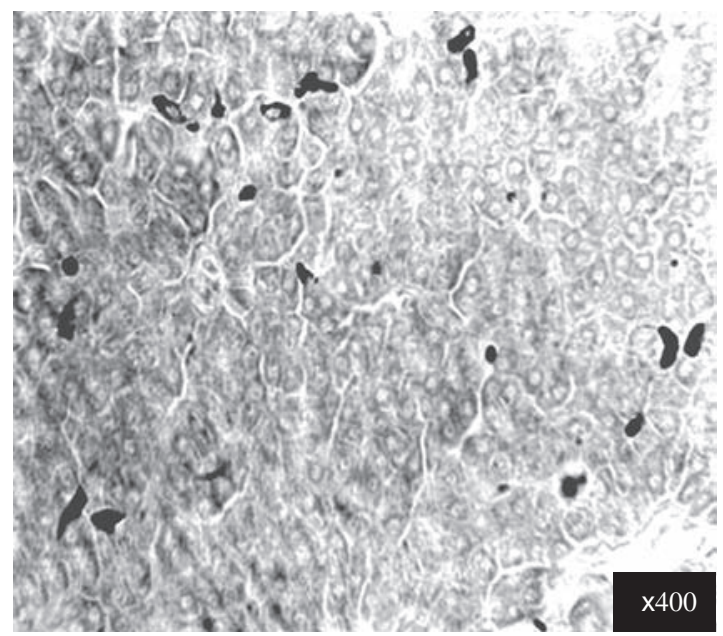

Figure 6. Optic photomicrography from the pancreas histological section of Zonotrichia capensis subtorquata. Note diffuse insulin-immunoreactive cells among pancreatic acini. 400x. ment with reports from Brazilian sparrow species whose type D cells are located around the pancreatic islets. On the other hand, the type A cells are sometimes located in the middle region and type $\mathrm{B}$ cells occurring isolated or in smaller groups throughout the exocrine pancreas.

An observation over type D cells cytoplasmic processes close to A and B cells corroborated the morphological evidence related to inhibitory effects performed by somatostatin on insulin and glucagon secretion supporting the hypothesis concerning a paracrine function by type D cells (Koerker et al., 1974).

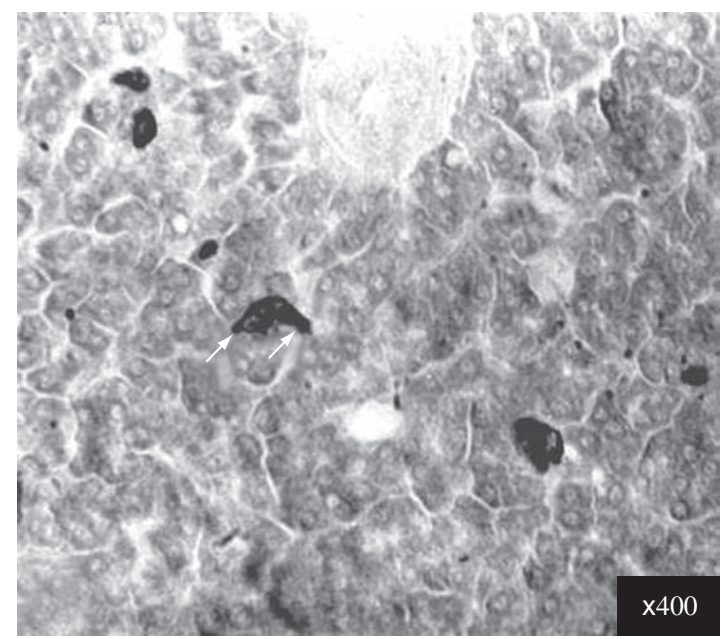

Figure 7. Optic photomicrography from the pancreas histological section of Zonotrichia capensis subtorquata. Note diffuse somatostatin-immunoreactive cells placed at the exocrine portion. Observe two stained adjacent cells showing cytoplasmic processes (arrows). 400x.

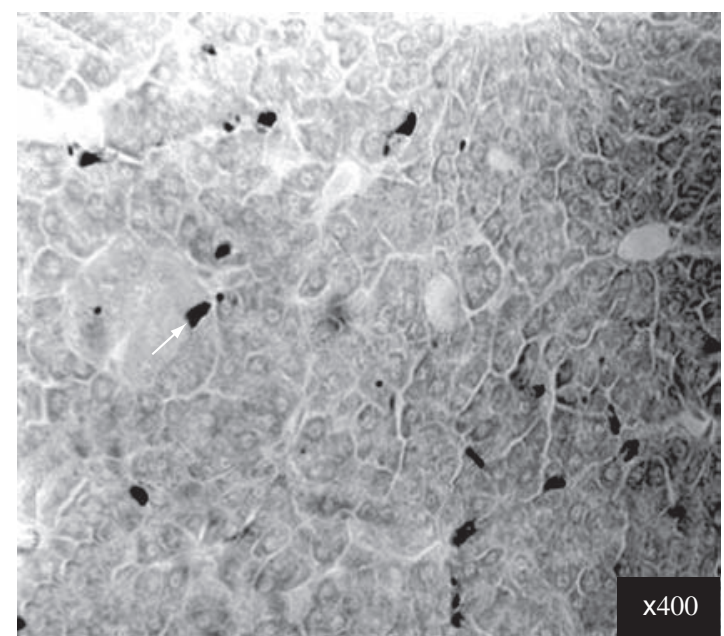

Figure 8. Optic photomicrography from the pancreas histological section of Zonotrichia capensis subtorquata. Note diffuse polypeptide YY-immunoreactive cells in the pancreas most of them are placed on the exocrine portion. Observe a stained cell in the islet of Langerhans (arrow). 400x. 
The particular localization of pancreatic glucagonimmunoreactive cells around the pancreatic islets has been observed in most of related species (Orci et al., 1976; Sundler et al., 1983; Cardoso et al., 1996). Data from our work have been similar those ones reported elsewhere. In regard to islet extra tissue the present results have agreed with Cardoso et al. (1996) in the endocrine pancreas of Tangara seledon species.

APP-immunoreactive cells were detected by immunocytochemical methods, in a lower frequency around pancreatic islets, however, in a greater number among pancreatic acini as well as isolated or in clusters in birds (Cardoso et al., 1996). This topographic distribution is coincident with that observation made of the pancreas of species studied. APP-immunoreactive cells were reported in the proventriculus (Yamada et al., 1985; Martinez et al., 1991 and 1993) and in the gizzard (Yamada et al., 1986b and Cardoso et al., 1999) of several birds. Some APP-immunoreactive cells showed cytoplasmic fibers as much as in the pancreatic islets and islet extra tissues, and sometimes, presenting a wide ending portion like a synaptic button according to Yamada et al. (1986a) reports in Caiman latirostris (Daudin, 1802) pancreas. Such morphologic characteristic, that is cytoplasmic extensions similar to nervous structures in APP-immunoreactive cells, suggest that it is associated to a paracrine regulation pattern over the neighboring cells in addition to an endocrine function.

Only a few PYY-containing cells were detected in pancreatic islets of Zonotrichia capensis subtorquata. Our results from the exocrine pancreas are similar to those ones reported by Cardoso et al. (1996), in the endocrine pancreas of Tangara seledon (Müller, 1776) species.

B cells were rather detected in the center of pancreatic islets, occurring, isolated or in smaller groups, in the exocrine parenchyma.

Insulin-immunoreactive cells were most prevalent in the middle of Brazilian sparrow species pancreatic islets as have been reported by Cardoso et al. (1996) in Tangara seledon pancreas.

The close association among A, B and D cells confirms earlier observations (Orci and Unger, 1975; Orci et al., 1975) constituting a morphologic support for a better understanding of glucagon and somatostatin roles over insulin secretion (Unger et al., 1978 and Trimble and Renold, 1981). The results obtained by the immunocytochemical method show five different kinds of cells: A, B, D, APP, PYY which were detected in the pancreas of Brazilian sparrow species.

Acknowledgments - We thank Prof. N. Yanaihara (University of Shizuoka, Shizuoka, Japan) for the preparation of the glucagon peptide, S. Ito Niigata (Japan) for the preparation of the somatostatin peptide, and Dr. J.R. Kimmel (Kansas City, USA) for providing the APP peptide.

\section{References}

CARDOSO, TRD., PINHEIRO, NL. and MOTA, DL., 1996. Estudo imunocitoquímico do pâncreas endócrino de Tangara seledon (Muller, 1776). Rev. Univ. Rural, Serie Ciência da Vida, vol. 18 , no. $1-2$, p. $85-89$.

CARDOSO,TRD.,PINHEIRO,NL.,MOTA,DL.andYAMADA, J., 1999. Identificação e localização das células endócrinas dos estômagos de Tangara seledon (Müller, 1776) (Passeriformes: Thraupinae) através de estudo imunocitoquímico. Rev. Univ. Rural, Serie Ciência da Vida, vol. 21, no. 1-2, p. 75-83.

DI FIORI MSH., 1975. Diagnóstico histológico. Tomo I. $7^{\mathrm{a}} \mathrm{ed.}$ Argentina Buenos Aires Libreria "El Ateneo". Editorial. 591p.

EERDUNCHAOLU, DV., TAKEHANA, K., KOBAYASHI, A., YAMADA. J., UEDA, H., BAIYIN, CAO, GF. and ABE, M., 2001. Immunohistochemical study of the distribution of endocrine cells in the gastrointestinal tract of the camel (Camelus bactrianus). Eur. J. Morphol. vol. 39, no. 1, p. 57-63.

HEYDERMAN E., 1979. Immunoperoxidase techniques in histopathology: aplications, methods and controls. J. Clin. Pathol., vol. 32, no. 10, p. 971-78.

HSU, SM., RAINE, L. and FANGER, H., 1981. Use of AvidinBiotin-Peroxidase Complex $(\mathrm{ABC})$ in immunoperoxidase techiques: A comparasion between $\mathrm{ABC}$ and unlabeled antibody (PAP) procedures. J. Histochem. Cytochem., vol. 29, no. 4 , p. $577-80$.

JUNQUEIRA, LC. and CARNEIRO, J., 2004. Biologia Celular e Molecular, Guanabara Koogan, Rio de Janeiro, 10ª ed., 488p.

KOERKER, DJ., RUEL, W., CHIDECKEL, F., PALMER, J., GEONDER, CJ., ENSICH, J. and GULE, CC., 1974. Somatostatin: Hypothalamic inhibitor of the endocrine pancreas. Science., vol. 184, no. 135, p. 482- 84.

KU,SK.,LEE, HS. andLEE, JH., 2003.Animmunohistochemical study of the gastrointestinal endocrine cells in the C57BL/6 mice. Anat. Histol. Embryol., vol. 32, no. 1, p. 21-8.

KU, SK., LEE, HS. and LEE, JH., 2000. An immunohistochemical study of endocrine cells in the alimentary tract of the red-bellied frog, Bombina orientalis. J. Vet. Med. Sci., vol. 62, no. 6, p. 589-94.

LUCINI, C., ROMANO, A. and CASTALDO, L., 2000. NPY immunoreactivity in endocrine cells duck pancreas: an ontogenetic study. Anat. Rec., vol. 259, no. 1, p. 35-40.

MARTINEZ, A., LOPEZ, J., BARRENECHEA, M. A. and SESMA, P., 1991. Immunocytochemical and ultrastructural characterization of endocrine cells in chicken proventriculus. Cel. Tissue Res., vol. 263, no. 3, p. 541-8.

MARTINEZ, A., LOPEZ, J and SESMA, P., 1993. Development of the diffuse endocrine system in the chicken proventriculus. Cell Tissue Res., vol. 271, no. 1, p. 107-13.

ORCI, L., BAETENS, D. DUBOIS, M. P. and RUFENER, C., 1975. Evidence for the D - cell of the pancreas secreting somatostatin. Horm. Metab. Res., vol. 7, no. 5, p. 400-02.

ORCI, L. and UNGER, RH., 1975. Functional subdivision of islets of Langerhans and possible role of D cells. Lancet, vol. 20, no. 2, p. 1243-44.

ORCI, L., BAETENS, D., RAVAZZOI. A, M., STEFAN, Y. and MALAISSE-LAGAE, F., 1976. Pancreatic polypeptide and glucagon: non-random distribution in pancreatic islets. Life Science., vol. 15, no. 19, p. 1811-15.

PAN, QS.,FANG,ZP. andZHAO, YX., 2000. Imunocytochemical identification and localization of APUD cells in the gut of seven 
stomachless teleost fishes. World J. Gatroenterol. vol. 6, no. 1, p. $96-101$.

SUNDLER, F., ALUMETS, J. and HAKANSON, R., 1983. The endocrine pancreas morphology, ontogeny and hormone production. Upsala J. Ailed, Sci. Suppl, vol. 39, p. 33-46.

TRIMBLE, ER. and RENOLD, AE., 1981. Ventral and dorsal areas of rat pancreas: islet hormone content and secretion. Am. J. Physiol Endocrinol Metab., vol. 240, no. 4, p. 422-27.

UNGER, RH., DOBBS, RE. and ORCI, L., 1978. Insulin, glucagons, and somatostatin secretion in the regulation of metabolism. Annu. Rev. Physiol., vol. 40, p. 307-43.

YAMADA, J., KITAMURA, N. and YAMASHITA, T., 1985. The relative frequency and topographical distribuition of somatostatin - GRP - APP - glucagon - 5 - HT and neurotensin - immunoreactive cells in the proventriculus of seven species of birds. Arch. Histol. Jpn, vol. 48, no. 3, p. 305-14.

YAMADA, J., CAMPOS, VJM., KITAMURA, N., PACHECO, AC., YAMASHITA, T. and YANAIHARA, N., 1986a. An immunohistochemical study of endocrine cells in the pancreas of Caiman latirostris (Alligatorinae), With special reference to pancreatic motilin cells. Biomed. Res., vol. 7, p. 199-208.

YAMADA, J., KITAMURA, N., YAMASHITA, T. and YANAIHARA, N., 1986b. Immunohistochemical studies on the endocrine cells in avian gizzard. Biomed. Res., vol. 7, p. 39-45. 